\title{
PENINGKATAN BERPIKIR KRITIS MAHASISWA MELALUI MODEL PEMBELAJARAN PROJECT CITIZEN
}

\author{
${ }^{1}$ Nadya Putri Saylendra \\ ${ }^{1}$ Dosen Pendidikan Pancasila dan Kewarganegaraan \\ Fakultas Keguruan dan Ilmu Pendidikan \\ Universitas Buana Perjuangan Karawang \\ email: nadya.saylendra@ubpkarawang.ac.id
}

\begin{abstract}
This study aims to describe of how Project Citizen plays a role in critical thinking of the students of Pancasila and Civic Education Program at Buana Perjuangan Karawang University in criminal law subject by seeing the response in understanding, and the level of effectiveness in using Project Citizen model. The approach used is a qualitative approach with descriptive study method. The result of this research is Project Citizen demands lecturer to do planning before doing the learning. Implementation of the Project Citizen model in Civics learning also demands to assist and direct the students to self-define a case / issue, to examine the problem, to formulate material related to the problem, to seek information from various sources, to account for the results of collecting the materials and analysis in the form of portfolio as well present the results with the creativity of the group presentation. Learning outcomes obtained through this learning model is the increasing ability of critical thinking students. The constraints and the most perceived factors in critical thinking vary widely both internally and externally such as laziness, lack of mastery of materials, lessons learned processes and learning situations, less challenging topics or issues.
\end{abstract}

Keywords: Critical Thinking, Civic Education, Project Citizen.

\begin{abstract}
ABSTRAK
Penelitian ini bertujuan untuk memperoleh gambaran bagaimana Project Citizen berperan dalam berpikir kritis mahasiswa Prodi PPKn di Universitas Buana Perjuangan Karawang dalam mata kuliah hukum pidana dengan melihat respon dalam pemahaman, dan tingkat efektifitas dalam menggunakan model Project Citizen. Pendekatan yang digunakan adakah pendekatan kualititatif dengan metode studi deskriptif. Hasil yang didapatkan dari penelitian ini adalah Project Citizen menuntut dosen untuk melakukan perencanaan sebelum melakukan pembelajaran. Pelaksanaan model Project Citizen dalam pembelajaran PKn juga menuntut untuk membantu dan mengarahkan mahasiswa untuk menentukan sendiri suatu kasus/isu, menelaah masalah, membuat rumusan materi yang berkaitan dengan masalah, mencari informasi dari berbagai sumber, mempertanggungjawabkan hasil pengumpulan materi dan analisis tersebut dalam bentuk portofolio serta mempresentasikan hasil dengan kreativitas penyajian kelompok. Hasil belajar yang didapatkan melalui model pembelajaran ini adalah meningkatnya kemampuan berpikir kritis mahasiswa. Faktor yang menjadi kendala dan yang paling dirasakan dalam berpikir kritis sangat bervariasi baik internal maupun eksternal seperti malas, kurangnya penguasaan materi, proses dan situasi pembelajaran di kelas, topik atau isu yang kurang menantang.

Kata Kunci : Berpikir Kritis, Pendidikan Kewarganegaraan, Project Citizen.
\end{abstract}




\section{PENDAHULUAN}

Pembelajaran selama ini berjalan dengan verbalistik dan berorientasi kepada penguasaan isi dari mata kuliah hukum pidana. Pengamatan terhadap praktek pembelajaran sehari-hari menunjukkan bahwa pembelajaran difokuskan agar mahasiswa menguasai informasi yang terkandung dalam materi perkuliahan dan kemudian dievaluasi seberapa jauh penguasaan itu dicapai oleh mahasiswa. Seakan-akan pembelajaran bertujuan untuk menguasai isi dari mata kuliah tersebut. Bagaimana keterkaitan materi ajar dengan kehidupan seharihari dan bagaimana materi tersebut dapat digunakan untuk memecahkan problema kehidupan, kurang mendapat perhatian. Pembelajaran seakan terlepas dari kehidupan sehari-hari, oleh karena itu mahasiswa tidak mengetahui manfaat apa yang dipelajari, seringkali tidak tahu bagaimana menggunakan apa yang telah dipelajari dalam kehidupan minimal bermasyarakat.

Bertolak dari masalah tersebut, kiranya perlu dilakukan langkah-langkah agar pendidikan dapat membekali peserta didik dengan kecakapan hidup, yaitu kemampuan dan keberanian menghadapi problema kehidupan, kemudian secara kreatif menemukan solusi serta mampu mengatasinya. Pendidikan yang dapat mensinergikan berbagai mata pelajaran/mata diklat/mata-kuliah menjadi kecakapan hidup yang diperlukan seseorang, di manapun ia berada, bekerja atau tidak bekerja, apapun profesinya. Dengan bekal kecakapan hidup yang baik, diharapkan para lulusan akan mampu memecahkan problema kehidupan yang dihadapi, termasuk mencari atau menciptakan pekerjaan bagi mereka yang tidak melanjutkan pendidikannya. Dan juga dapat "...mendorong keterbukaan intelektual, ..." (Jawwad, 2004: 48). Pembelajaran merupakan bagian atau elemen yang memiliki peran yang sangat dominan untuk mewujudkan kualitas baik proses maupun lulusan (output) pendidikan. Dan hal ini pun sangat tergantung pada tenaga pengajar dalam melaksanakan proses belajar mengajar di kelas.

Kompleksitas perkembangan permasalahan kewarganegaraan, Wahab (2011:13-14) mengatakan bahwa perkembangan Pendidikan Kewarganegaraan di era global telah terjadi pergeseran dari penekanan pada kebenaran yang bersifat monovision kepada multivision yang implikasinya pada tuntutan berpikir secara kompleks sehingga cara-cara berpikir linear sering tidak relevan lagi. Warga negara dituntut memiliki keterampilan dalam menjalani kehidupan di abad ke-21 ini, agar memberikan implikasi pada dunia pendidikan untuk menyesuaikan dan meresponnya. Berkaitan masalah keterampilan atau kecakapan warga negara Soemantri (2011) dalam The making of innovative human resources mengedepankan charateristics of innovative humman resources yang unsurnya adalah hard skills dan soft skills yang menurutnya harus dipertahankan.

Berkaitan dengan hal di atas, UNESCO telah menyatakan bahwa belajar di abad 21 didasarkan kepada empat pilar yaitu: (1) Learning how to know, (2) Learning to do, (3) Learning to be, (4) Learning how to live together. Keempat hal tersebut sering disebut sebagai soko guru dari pembangunan sumber daya manusia 
abad 21 untuk menghadapi arus informasi dan kehidupan yang terus menerus berubah.

Pengajaran dan pendidikan adalah dua hal yang berbeda. Sedangkan saat ini sering terjadi lebih menitik beratkan pengajaran sehingga menyampingkan pendidikan. Proses pengajaran yang menitikberatkan pada aspek kognitif dan kemampuan teknis semata justru akan melahirkan manusia pekerja dan bukan seorang pemimpin yang kaya akan inovasi serta memiliki komitmen sosial yang kuat. Pembelajaran yang bersifat demokratis, harus memiliki tujuan menghasilkan lulusan yang mampu berpartisipasi dalam kehidupan masyarakat dan mampu mempengaruhi pengambilan keputusan kebijakan publik. Dengan kata lain, pembelajaran harus mampu menenemkan kesadaran dan membekali berperan sebagai warga negara dalam masyarakat yang demokratis.

Untuk menjawab tantangan tersebut, perlu adanya peningkatan berpikir kritis yang juga dipandang sebagai salah satu unsur pembentukan karakter bangsa Indonesia sudah sangat mendesak untuk dilakukan. Dalam membentuk karakter bangsa melalui Pendidikan Kewarganegaraan yang memiliki komponen civic skills, yang termasuk didalamnya tentang intellectual skills. Pendidikan Kewarganegaraan semestinya tidak hanya mengembangkan

pemahaman/pengetahuan (civic knowledge) saja tetapi juga mengembangkan berpikir keritis (civic skills) agar mahasiswa dapat berpikir bagi dirinya sendiri untuk menghadapi kehidupan menuju masa depan dan berpartisipasi secara baik (civic participation). Hal ini pendidikan harus mempersenjatai peserta didik dengan keterampilan agar dapat menghadapi perkembangan dunia dan semakin terbuka untuk persaingan, dengan demikian pendidikan dapat melindungi masyarakat yang semakin terbuka dan kompleks.

Pendidikan kewarganegaraan di era reformasi misalnya, harus dpat melakukan pergeseran paradigma pembelajaraannya ke arah paradigma baru yang menunjukan pendidikan Kewarganegaraan di era Indonesia baru. Di dalam paradigma sekarang menurut Wahab (2010:709) lebih diupayakan untuk menyiapkan warga negara yang demokratis, cerdas dan religius. Makna "warga negara yang baik" yang merupakan tujuan dari Pendidikan Kewarganegaraan masa lalu menurutnya dapat lebih diperjelas pada pengertian "warga negara yang demokratis dan berkarakter". Mengatasi hal tersebut dibutuhkan inovasi dalam pembelajaran yang dapat mengembangkan dan membiasakan berpikir secara kritis.

Salah satu inovasi model pembelajaran yang dapat meningkatkan berpikir kritis siswa adalah Project citizen. Model pembelajaran berbasis proyek ini memiliki daya tarik didalam langkah-langkah pembelajarannya. Daya tarik itu dimulai dari mencari data, membuat portofolio baik tayangan maupun dokumen yang sangat menunjang cara kerja ilmiah. Kemudian secara objektif telah dikemukakan oleh orang lain serta hasil penelitian terdahulu misalnya hasil penelitian dalam lingkup lokal seperti pada hasil penelitian Suabuana dan Maksum menunjukan bahwa pada kelas-kelas Project 
citizen menunjukan lebih baik di bandingkan kelas konvensional. Begitu juga hasil yang dilaporkan oleh International Democratic Educational Institute (Craddock et.al, 2007) berkesimpulan bahwa Project citizen memberikan dampak bagi pengetahuan, sikap dan keterampilan kewarganegaraan siswa. Meskipun demikian, ruang lingkup dan presentase pengaruh ini sangat beragam di antara berbagai kawasan di beberapa Negara.

Berdasarkan alasan-alasan di atas baik alasan subjektif maupun objektif mengapa Project citizen, maka penelitian menentukan judul "Implementasi Projetc Citizen dalam Berpikir Kritis Mahasiswa (Studi Deskriptif terhadap Mata Kuliah Hukum Perdata pada Prodi PPKn Universitas Buana Perjuangan Karawang)".

\section{Rumusan Masalah}

Bertolak dari latar belakang masalah di atas rumusan masalah penelitian yaitu "Bagaimana Implementasi Projetc Citizen dalam Berpikir Kritis Mahasiswa?". Berdasarkan masalah penelitian di atas, dirumuskan pertanyaan-pertanyan sebagai berikut:

1. Bagaimana persepsi mahasiswa mengenai elemen berpikir kritis (sikap positif untuk berpikir kritis, kemampuan berpikir kritis dan karakteristik berpikir kritis)?

2. Bagaimana dosen merencanakan Project Citizen dalam berpikir kritis mahasiswa?

3. Bagaimana pelaksanaan pembelajaran menggunakan Project Citizen dalam kemampuan berpikir kritis mahasiswa?

4. Bagaimana hasil belajar melalui Project Citizen dalam kemampuan berpikir kritis mahasiswa?

5. Faktor determinan apa saja yang dapat meningkatkan kemampuan berpikir kritis mahasiswa?

\section{Tujuan Penelitian}

1. Mendeskripsikan bagaimana persepsi mahasiswa mengenai elemen berpikir kritis (sikap positif untuk berpikir kritis, kemampuan berpikir kritis dan karakteristik berpikir kritis).

2. Mendeskripsikan bagaimana dosen merencanakan Project Citizen dalam berpikir kritis mahasiswa.

3. Mendeskripsikan bagaimana pelaksanaan pembelajaran menggunakan Project Citizen dalam kemampuan berpikir kritis mahasiswa.

4. Mendeskripsikan bagaimana hasil belajar melalui Project Citizen dalam kemampuan berpikir kritis mahasiswa.

5. Mendeskripsikan faktor determinan apa saja yang dapat meningkatkan kemampuan berpikir kritis mahasiswa.

\section{METODE}

Pendekatan yang digunakan dalam penelitian ini adalah pendekatan kualitatif. Seperti yang dikemukakan oleh Nasution (2003:5), bahwa hakikat penelitian kualitatif adalah "untuk mengamati orang dalam lingkungan hidupnya, berinteraksi dengan mereka, berusaha memahami bahasa dan tafsiran mereka tentang dunia sekitar". Adapun alasan penggunaan pendekatan ini adalah karena ia mampu lebih mendekati peneliti dengan objek yang dikaji, sebab peneliti langsung mengamati objek yang dikaji dengan kata lain peneliti 
bertindak sebagai alat utama riset (human instrumen).

Maka dari itu, peneliti ingin mengetahui bagaimana implementasi Project Citizen dalam berpikir kritis mahasiswa. Sehingga peneliti memperoleh gambaran dari permasalahan yang terjadi secara mendalam (berupa kata-kata, gambar, prilaku) dan tidak dituangkan dalam bentuk bilangan atau angka statistik, melainkan tetap dalam bentuk kualitatif.

Selain itu, metode penelitian yang digunakan dalam penelitian ini adalah metode deskriptif. Dalam penelitian tersebut berusaha menggambarkan peristiwa dan kejadian yang menjadi pusat perhatian penelitian ini. Adapun pengertian metode deskriptif menurut Sudjana dan Ibrahim (1989:64) yaitu:

Pengertian deskriptif adalah penelitian yang berusaha mendeskripsikan suatu gejala, peristiwa, kejadian yang terjadi pada saat sekarang dengan perkataan lain, penelitian deskriptif mengambil masalah atau memusatkan perhatian kepada masalah-masalah aktual sebagaimana adanya pada saat penelitian dilaksanakan.

Hasil analisis dari penelitian ini berupa pemaparan gambaran mengenai situasi objek yang diteliti dalam bentuk uraian naratif.

\section{Lokasi Penelitian}

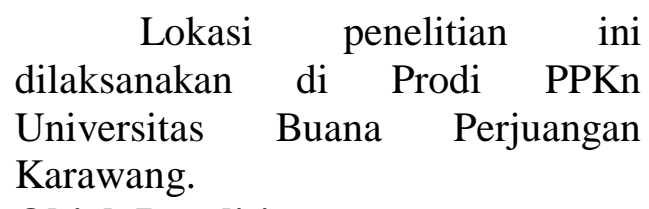

\section{Objek Penelitian}

Objek dalam penelitian ini adalah, dosen mata kuliah hukum pidana dan mahasiswa Prodi. PPKn angkatan 2015 . Jadi dalam penelitian ini, peneliti tidak mengambil secara keseluruhan komponen-komponen yang ada di Universitas Buana Perjuangan Karawang.

\section{Teknik Pengumpulan Data}

Ada pun teknik penelitian yang digunakan dalam proses pengumpulan data adalah sebagai observasi, wawancara, studi literatur dan studi dokumentasi.

\section{Teknik Pengolahan Data}

Penelitian ini merupakan penelitian kualitatif sehingga data yang diperoleh adalah berupa katakata yang diperoleh dari berbagai sumber melalui wawncara dan pengamatan. Setelah data diperoleh dari berbagai sumber, langkah selanjutnya melakukan prosedur pengolahan dan analisa data. Mulamula data yang sudah ada ditelaah dan diperiksa kemudian dirangkum dan difokuskan pada hal-hal yang penting sesuai dengan permasalahan dan disesuaikan dengan fokus masalah penelitian selanjutnya dianalisis dan diperiksa keabsahannya.

Data terkumpul diklarifikasikan dan dikategorikan sesuai dengan fokus penelitian. Berdasarkan hasil pengumpulan data yang telah peneliti dapatkan yaitu dari hasil wawancara, observasi, dan dokumentasi, maka peneliti melakukan melalui tiga alur kegiatan yaitu: reduksi data, display data dan kesimpulan / verifikasi data.

Teknik Analisis Data

Data yang bersifat kualitatif pertama-tama dikumpulkan terlebih dahulu. Setelah semua terkumpul, kemudian dikategorisasikan 
berdasarkan fokus penelitian dan dianalisis. Kegiatan analisis data ini meliputi : penyeleksian data, pengelompokan data untuk memudahkan pengolahan data, mentabulasi data untuk mempermudah membaca data, dan menafsirkan data.

\section{Pengujian Keabsahan Data}

Prosedur validasi ini bermanfaat dan sekiranya dapat mempermudah dalam pengujian keabsahan data-data yang telah diperoleh. Sugiyono (2008: 366) menjelaskan bahwa " uji keabsahan data dalam penelitian kualitatif meliputi uji credibility (validitas Internal), transferability (validitas eksternal), dependability (reliabilitas), dan confirmability (obyektivitas)".

\section{HASIL PENELITIAN}

Pemahaman mahasiswa mengenai berpikir kritis mencakup sikap positif, kemampuan dan karakter berpikir positif belum semuanya memenuhi persepsi yang ideal. Project Citizen ini tentu saja menuntut dosen untuk melakukan perencanaan sebelum melakukan pembelajaran. Ketentuan yang seharusnya dilakukan oleh dosen adalah membuat silabus dan RPS yang di dalamnya mencakup tujuan pembelajaran, materi yang akan dibelajarkan, model yang akan diterapkan, media yang akan digunakan, sumber pembelajaran yang digunakan, serta evaluasi pembelajaran.

Pelaksanaan model Project Citizen dalam pembelajaran PKn menuntut untuk membantu dan mengarahkan mahasiswa untuk menentukan sendiri suatu kasus/isu, menelaah masalah, membuat rumusan materi yang berkaitan dengan masalah, mencari informasi dari berbagai sumber, mempertanggungjawabkan hasil pengumpulan materi dan analisis tersebut dalam bentuk portofolio serta mempresentasikan hasil dengan kreativitas penyajian kelompok.

Hasil belajar yang didapatkan melalui model pembelajaran ini adalah meningkatnya kemampuan berpikir kritis mahasiswa. Dari kegiatan tersebut mampu memberikan pengalaman dan bekal bagi siswa dalam kehidupan di masyarakat dengan setiap aspek permasalahannya. Faktor yang menjadi kendala dan yang paling dirasakan dalam berpikir kritis sangat berfariasi baik internal maupun eksternal seperti malas, kurangnya penguasaan materi, proses dan situasi pembelajaran di kelas, topik atau isu yang kurang menantang.

\section{SIMPULAN}

Kesimpulan yang diperoleh dari hasil penelitian yang telah dilakukan yaitu melalui Project Citizen, kemampuan berpikir kritis siswa dapat ditingkatkan secara signifikan melalui hasil belajar yang dikeluarkan setelah pembelajaran. Dalam pelaksanaannya, Project Citizen ini menginginkan dosen untuk merencanakan pembelajaran yang akan diterapkan. Ketentuan yang seharusnya dilakukan oleh dosen adalah membuat silabus dan RPS yang di dalamnya mencakup tujuan pembelajaran, materi yang akan dibelajarkan, model yang akan diterapkan, media yang akan digunakan, sumber pembelajaran yang digunakan, serta evaluasi pembelajaran. Faktor umum yang menjadi kendala dan yang paling dirasakan dalam berpikir kritis sangat bervariasi baik internal maupun eksternal seperti malas, penguasaan 
materi, proses dan situasi pembelajaran di kelas, topik atau isu yang kurang menantang.

\section{Saran}

Perlu mengagendakan project citizen dalam proses pembelajaran mengingat banyak kelebihan dari model ini untuk mengembangkan karakteristik berpikir kritis hingga tercapai hasil yang diharapkan. Dalam proses pembelajaran, dosen perlu meninjau kembali materi, kompetensi yang ingin dicapai serta elemen dan indikator berpikir kritis yang ingin dikembangkan, agar dalam proses pembelajaran selain menyampaikan materi juga memberikan pemahaman berpikir kritis dan bagaimana aplikasinya saat problem solving.

\section{DAFTAR REFERENSI}

Budimansyah, D. (2009). Inovasi Pembelajaran Project Citizen. Bandung: Program Studi PKn SPs UPI.

Craddock, et.al, (2007) "Theaching for Democracy: Assessing Project Citizen in Poland, South Africa", Research Report.

Gunawan, Adi W. 2003. Genius Learning Strategy Petunjuk Praktis untuk Menerapkan Accelarated Learning. Jakarta. Gramedia Pustaka Utama.

Juha, Mervat Amin. 2010. Thinking Skills Critical Thinking- 2 Chapter. Zaid.IQ

Maftuh, B (2008) Internalisasi NilaiNilai Pancasila dan Nasionalisme melalui Pendidikan Kewarganegaraan. Jurnal Educationist, Vol II, No 2, Juli 2008.

Nasution, S. (2007). Metode Research (Penelitian Ilmiah). Jakarta: Bumi Aksara.
(2003). Metode

Penelitian. Bandung: Tarsito.

Potter, Mary Lane .2010. From

Search to

Research:Developing Critical

Thinking Through Web

Research Skills@ 2010

Microsoft Corporation.

Rahmat. 2010. Pengukuran

Ketrampilan Berpikir Kritis. (Online)

Soemantri, B. (2011). "The Making

of Innovative Human

Resources": Makalah

Seminar dalam rangka dies natalis UKSW ke 55, Salatiga.

Sudjana \& Ibrahim. 1989. Desain dan Analisis Eksperimen. Bandung: Tarsito.

Sugiyono. 2008. Metode Penelitian Kuantitatif Kualitatif dan $R \& B$. Bandung: Alfabeta.

Toffler, A. (1981). The Third Wave, Bantam Books, Inc., New York.

Turner, et al. (1990). Civics: Citizen In Action. United States of America: Merril Publishing Company.

Wahab, A, A dan Sapriya. (2011). Teori dan Landasan PKn. Bandung: Alfabeta 